\title{
Does Organizational Learning Affect R\&D Engineers' Creativity?
}

\author{
Cheng Ling $\operatorname{Tan}^{1} \&$ Yen Ping Chang ${ }^{1}$ \\ ${ }^{1}$ Graduate School of Business, Universiti Sains Malaysia, Penang, Malaysia \\ Correspondence: Cheng Ling Tan, Graduate School of Business, Universiti Sains Malaysia, 11800 Penang, \\ Malaysia. Tel: 60-46-53-2896. E-mail: tanchengling@usm.my
}

Received: February 9, 2015 Accepted: May 26, 2015 Online Published: June 13, 2015

doi:10.5539/ass.v11n16p137 URL: http://dx.doi.org/10.5539/ass.v11n16p137

\begin{abstract}
R\&D engineers are viewed as the vital source of creativity and innovation for the companies to improve its business values, in particular in the original design manufacturer (ODM) companies. In order to promote R\&D engineers' creativity within the organization, organizational learning is viewed to be well shaped to enhance creativity of the engineers. Therefore, this study aims to determine the effect of perceived organizational learning towards the research and development (R\&D) engineers' creativity in the ODM companies in Malaysia. The perceived organizational learning was conceptualized into four dimensions of managerial commitment, systems perspective, openness and experimentation, and knowledge transfer and integration. Structural Equation Modeling (SEM) was employed to test the model using SMART-PLS version 2.0 package, drawing on a sample of 140 R\&D engineers working in the ODM companies in Malaysia. Data analysis revealed that, all four dimensions of organizational learning contribute the significant impact on R\&D engineers' creativity. The results offer a number of suggestions to ODM firms in Malaysia. Specifically, organization can establish a platform to enable its R\&D engineers to acquire, exchange and apply knowledge within the team or even organization. In doing so, the employees can utilise the knowledge to create new solutions, improve efficiency and solve issues encountered in the organization and this definitely will increase the R\&D engineers' creativity.
\end{abstract}

Keywords: creativity, organizational learning, research and development, operations costs, Malaysia

\section{Introduction}

In ODM industry, talent usually refers to the R\&D engineers. The ODM firms are very much depended on R\&D engineers, who are viewed as the source of creativity and innovation for the firms to improve its business values and to sustain the firm's position in this ever changing and highly competitive market. In the 10th Malaysia Plan (10MP), Talent Corporation (TC) is setup by Malaysia Prime Minister for the purpose to attract, nurture and retain talent required for Malaysia to achieve high income economy (Economic Planning Unit, 2010), which is in line with the Economic Transformation Program (ETP) and to bring Malaysia's growth path back to the trajectory towards Vision 2020 (Performance Management and Delivery Unit (PEMANDU, 2011). One of the challenges that Malaysia wishes to overcome is to establish a scientific and progressive society that is innovative and forward-looking.

TC is progressively developing collaborative initiative among industries by rolling out various R\&D projects at several ODM firms (Performance Management and Delivery Unit (PEMANDU, 2012a). These ODM firms comprise of semiconductors, solar, light emitting diode (LED) and industrial electronic, which are the important contributors to Malaysian economy, approximates to provide incremental Gross National Income (GNI) of 11.53 billion and creates 36,900 jobs by 2020 (Performance Management and Delivery Unit (PEMANDU, 2012b). This denotes that Malaysia is highly demand for the R\&D engineers to work in the ODM industries for the near future.

From the national perspective, Malaysia's GERD of RM9.4 billion shows an increment of threefold compared to 2006 at RM3.6 billion. From the global perspective, Malaysia's GERD/GDP ratio of 1.07 in 2011 was considered low compared to other Asia Pacific countries like Singapore, China, Korea and Japan which accounted for 2.3, 1.8, 3.7 and 3.3 respectively (Agency for Science, Technology and Research Singapore, 2012). Besides, the Global Innovation Index published by Cornell University, INSEAD, WIPO (2014) indicated that Malaysia's score values of 45.60 (100 is the best) was lower compared to compared to China (46.57), Singapore (59.24), Korea (55.27), and Japan (52.41). Nonetheless, this indicates that Malaysia still has room to catch up its 
$R \& D$ and innovation performance with these countries.

In order to promote $R \& D$ engineers' creativity within the organization, organizational learning is viewed to be well shaped to enhance creativity of the engineers, namely managerial commitment, systems perspective, openness and experimentation, and knowledge transfer and integration (Jerez-Gomez, Céspedes-Lorente, \& Valle-Cabrera 2005; Senge, Kleiner, Roberts, Ross, Roth, \& Smith, 1999). Thus, this study aims to explore the influence of organizational learning that might help to increase the R\&D engineers' creativity level.

\section{Literature Review}

\subsection{Craetivity}

Creativity can be viewed from various dimensions. Earlier research by Donnelly (1994) viewed creativity as the ability to see and transform materials and objects into new and original forms. Lately, Nettle (2002) viewed the creative as gifts of the person with a schizotypal personality. Yet, Batey and Furnham (2006) termed creativity as the capacity to suggest many different uses for an object. Generally, creativity can be defined as the generation of new, original and useful idea (Berg, Taatila, \& Volkmann, 2012). Practical application of creativity can be considered as an innovation (Escriba-Esteve \& Montoro-Sanchez, 2012). Therefore, the spark of creativity which will generate the ideas leading to the birth of innovation should be acclaimed in the organization.

In order to improve creativity in organization, three aspects are required, namely expertise, creative thinking skills, and intrinsic and extrinsic motivation (Amabile, Schatzel, Moneta, \& Kramer, 2004). These three aspects depend greatly on the organization itself, for example providing sufficient training and exposure to increase the expertise of the individual. This will then in turn to increase individual's creative thinking skills that can be amplified with both intrinsic and extrinsic motivation (Amabile et al., 2004).

Creative individual will produce useful ideas leading to improved organizational products, practices or procedures (Shalley \& Gilson, 2004). Nonetheless, if the ideas are not processed to have an ultimate conclusion, they will be remained as the random thought and interesting observation. In order to best capture creative ideas, the individual's new ideas need to be acquired, transferred and stored into knowledge bank where it can be converted into innovation. This is particularly vital for organization especially ODM firms that need to survive in the midst of rapid scientific and technological advancement.

In ODM industries, R\&D organization always focuses on the development of creative work that needs to be tackled regularly to improve knowledge, thus allowing it to be used for conceiving new products. R\&D activities cover the areas such as the basic research, strategic research, applied research and also experimental research and development. This activities naturally requires huge sums of investment in time and capital as well as the committed talents (Asmawi \& Mohan, 2010). R\&D engineers are usually the company's elite talent and their ultimate job responsibility is to generate creative ideas that contribute to the development of innovations. The endurance of the company is very much depended on its R\&D engineers' ability to continually improve and revolutionize the new products. Therefore, $R \& D$ engineers are required to be equipped not only with the core engineering competency and common sense, but also need to possess exploratory abilities, creativity and consciousness of global market situation (Chen, Sandhu, \& Jain, 2009).

\subsection{Perceived Organizational Learning}

Over recent years, organizational learning has turned into an emerging topic from different perspectives. Some studies viewed it from mental approach, sociological approach and also from the view of organizational theory. The learning has been considered, from a tactical view, to have significant value to the firm through R\&D innovations. This approach allows the blooming of new concept of organization learning, that move away the old method of resolving issues with the management.

Organizational learning is a lively practice based on knowledge, which suggest shifting among the different levels of action, from the individual level to the group level, and then to the organizational level and back again (Jerez-Gomez et al., 2005). This activity comes from the knowledge acquisition from the individuals and progresses with the exchange and integration of the knowledge until a corpus of collective knowledge is created and retained in the organizational processes and culture (Egan, Yang, \& Bartlett, 2004). This collective knowledge has the influence on the information acquired and how it is processed and distributed.

In order to develop the effective organizational learning capability, it requires four conditions. First, the management must provide strong support to organizational learning. Manager should lead the project, thus making clear of his commitment and his attempt to get all the personnel onboard (Jamal, 2011). Second, the management needs to facilitate an atmosphere of openness that would give the perspective of the firm to be seen as a system in which each element is free to make its own contribution so as to obtain a satisfactory result (De 
Geus, 1988; Senge et al., 1999). If a shared vision is lacking, the individual action will not contribute towards organizational learning (Small \& Irvine, 2006). Third, the management needs to continuously grow the organizational knowledge, based on the transfer and integration of knowledge from individually (Nonaka \& Peltokorpi, 2006). Creating a corpus of organizational knowledge, in the routines and processes of the work itself, is crucial for guaranteeing the organization's continuous learning (Daft \& Weick, 1984). Last but not the least, simply adapting to the changes within the established framework does not due to difference in economy and market would render the universal model inadequate to cope with its current competitive environment (Chiva, Alegre, \& Lapiedra, 2007). The firm must try to go beyond an adaptive learning and focus on the learning level that needed to build up the organizational system in force. If necessary, be bold to make changes for more innovative and flexible alternatives, generative learning (Senge et al., 1999); a learning that requires an open mentality towards new ideas and a great deal of experimentation (Jerez-Gomez et al., 2005).

Based on the above mentioned discussion, we concluded that organizational learning shall comprises of four dimensions, namely management commitment, system perspective, openness and experimental, and knowledge transfer and integration. Manageral commitment refers to the organization responsibility to enable its employees comprehend the value of learning and share actively in the firm's success (Chen, Silverthorne, \& Hung, 2006; Jerez-Gomez et al., 2005). System perspective refers to the organization ability to bringing the organization's employees collectively with the same identity (Senge et al., 1999). Openness and experimentation is regarded as the mood of openness that salutes the coming of raw views and points of thought, both inside and outside while experimentation allows for generative learning agreeing self-knowledge to be perpetually transformed, broadened, and revisited (Senge et al., 1999). Knowledge transfer and integration is viewed as the simultaneous occurrence of both processes rather than successively. The source of these two processes is from the knowledge absorptive capacity perspective from organization to individual and vice versa (Camisón \& Forés, 2010; Rhodes, Lok, Hung, \& Fang, 2008).

\subsection{The Relationship between Perceive Organizational Learning and R\&D Engineers' Creativity}

Organizational learning has been widely acknowledged that is positively influence on innovation (Garcia-Morales, et al., 2007). There are numerous studies that relate organizational learning to innovation at organization level (Akgun, Byrne, Lynn, \& Keskin, 2007; Alegre \& Chiva, 2008; Garcia-Morales, Lloréns-Montes, \& Verdú-Jover, 2007; Liao \& Wu, 2010). However, not much research have been studied the relationship between organizational learning with innovativeness at individual level (Chang, Yeh, Chen, \& Hsiao, 2011). Organizational learning is a process which consists of group of individuals that learn through interaction with its surrounding environment (Sinkula, 1994), which actually serves as primary driver for creativity. This means that organizational learning will enable individuals in the organization to continuously create new idea and new products. Since organizational learning has been identified as having four dimensions: management commitment, system perspective, openness and experimentation, and knowledge transfer and integration, our main hypothesis is as follow,

H1: Perceived organizational learning (management commitment, system perspective, openness and experimentation, and knowledge transfer and integration) has positive influence on the R\&D engineers' creativity.

The managerial commitment is vital to drive the process of change, taking the responsibility for creating an organization that is able to regenerate itself and face up to new challenges (Lin, 2008). Management who is committed will be able to develop and facilitate leadership management and managerial support for the innovation process and to motivate employee in creating and building knowledge in an organization (Ussahawanitchakit, 2008). This means that managerial commitment will motivate the R\&D engineer to be creative in contributing the new idea and knowledge to develop new product and new process. The aforementioned discussion has led to our first sub-hypothesis as below.

\section{H1a: Perceived managerial commitment has positive influence on the R\&D engineers' creativity}

The organization can be seen as a system that is made up of different parts, each with its own function but act in a coordinated manner (Senge et al., 1999). In order to viewing the firm as a system requires recognizing the importance of each relationships based on the exchange of information and services (Voltmer, Rosta, Siegrist, \& Aasland, 2012) and the development of shared mental models of organizational learning (Senge et al., 1999). Via the shared mental model, the R\&D engineers' capabilities to create, disseminate, and apply knowledge which is critical factors in determining the R\&D engineers creatively can be greatly enhanced. This system perspective allows the R\&D engineers' creativity includes generating new (novel or adopted) ideas and solutions, developing new product and new method, and producing an applicable prototype or model for the use of the organization 
(Hwang \& Kandampully, 2012). In line with discussion, our second sub-hypothesis is conjectured as below.

H1b: Perceived system perspective has positive influence on the R\&D engineers' creativity

The openness to new ideas are coming from within the organization or from outside of the organization. The favors experimentation which is an essential aspect for learning to be sustained as it implies the continuous search for innovative and flexible solutions to current and future problems (Jerez-Gomez et al., 2005). Experimentation ultimately requires the organization to have a culture that allows the taking of controlled risks, based on the supporting fact even in failure, one can still learn from one's mistakes (Jerez-Gomez et al., 2005). Based on Senge et al. (1999), in order to have conducive learning environment or double loop learning, it requires a climate of openness that allows acceptance of new ideas and points of view, thus allowing individual knowledge to be constantly renewed, widened, and improved, and thus increase the individual creativity. When organization has a climate of openness and experimentation in accepting new ideas and points of view in both internal and external aspects, this will increase $R \& D$ engineers' creativity. Therefore, the third sub-hypothesis is presented as below.

H1c: Perceived openness and experimental has positive influence on the R\&D engineers' creativity

When knowledge is transferred and integrated, the learning process will occur to improve the stock of knowledge available to the organization and to amplify the value of its intellectual assets, such as R\&D engineers' creativity (Chen et al., 2009). If an organization demonstrates competence in knowledge transfer and integration, it can be considered as having a knowledge management orientation (Darroch \& McNaughton, 2002). In such organization, R\&D engineers are willing to transfer the knowledge and they will be seen to have the higher creativity level. Hence, the following sub-hypothesis is developed.

H1d: Perceived transfer and integration has positive influence on the R\&D engineers' creativity

\section{Method}

\subsection{Sample and Data Collection Procedure}

The respondents of this study were R\&D engineers who are employed in the ODM organization in Malaysia. The ODM sector chosen in this study consists of semiconductors, solar, light emitting diode (LED), medical and industrial electronic. Meantime, there is no list published for the ODM companies. Based on the directory of Federation of Malaysia Manufacturer (2013), we found more than 300 companies involved in the ODM sectors. Among these companies, we found that only 40 companies have $R \& D$ facilities. The confirmation is carried out through telephone calls and website verification. A total of 600 questionnaires of were sent by postal services to the 40 ODM companies with the intention of getting 15 respondents from each company. Each packet contained of 15 questionnaires will then be distributed to $R \& D$ engineers by the department manager. Four weeks were given to the company to collect the questionnaires from the R\&D engineers. Once the assigned questionnaires have been collected, the department manager will mail them back to us. After several follow up calls, we manage to collect 142 questionnaires returned within two months period which yield a response rate of $23.6 \%$ percent. Out of 142 questionnaires, only 140 questionnaires customers were found usable for data analysis. Two questionnaires were not usable due to missing information.

\subsection{Measurements}

In this study, R\&D engineers' creativity was assessed with 5 items adapted from Houghton and DiLiello (2010). Meanwhile, the measurements of the four dimensions of perceived organizational learning were adapted from Jerez-Gomez et al. (2005), where 5 items used to measure managerial commitment; 3 items to gauge system perspective; 4 items to measure openness and experimental; and 4 items to measure knowledge transfer and integration. The response was based on five-point Likert scale (" 1 " = "strongly disagree" to " $5=$ "strongly agree"). Table 1 posits the measurement items used in this study.

Table 1. Measurement items of the study

\begin{tabular}{ll}
\hline Variables & Items \\
\hline & I have opportunities to use my creative skills and abilities at work \\
& I am invited to submit ideas for improvement in the workplace \\
R\&D & engineers' \\
creativity & $\begin{array}{l}\text { I have the opportunity to participate on team(s) } \\
\text { I have the freedom to decide how my job tasks get done } \\
\text { My creative abilities are used to my pull potential at work }\end{array}$ \\
\hline
\end{tabular}




\begin{tabular}{|c|c|}
\hline Variables & Items \\
\hline \multirow{5}{*}{$\begin{array}{l}\text { Managerial } \\
\text { commitment }\end{array}$} & The managers frequently involve their staff in important decision making processes \\
\hline & Employees learning is considered more of an expense than an investment \\
\hline & $\begin{array}{l}\text { My organization's management looks favorably on carrying out changes in any area to } \\
\text { adapt to and /or keep ahead of new environmental situations }\end{array}$ \\
\hline & Employee learning capability is considered a key factor in my organization \\
\hline & In my organization, innovative ideas that work, are rewarded \\
\hline \multirow[t]{3}{*}{ System perspective } & All employees have generalized knowledge regarding my organization's objectives \\
\hline & $\begin{array}{l}\text { All parts that made up my organization (department, section, work teams and individual) } \\
\text { are Ill aware of how they contribute to achieving the overall objectives }\end{array}$ \\
\hline & $\begin{array}{l}\text { All parts that make up my organization are interconnected, working together in an } \\
\text { coordinated fashion }\end{array}$ \\
\hline \multirow[t]{4}{*}{$\begin{array}{l}\text { Openness } \\
\text { experimental }\end{array}$} & $\begin{array}{l}\text { My organization promotes experimentation and innovation as a way of improving the } \\
\text { work processes }\end{array}$ \\
\hline & $\begin{array}{l}\text { My organization follows up what other firms in the sector are doing, adopting those } \\
\text { practices and techniques it believed to be useful and interesting }\end{array}$ \\
\hline & $\begin{array}{l}\text { Experiences and ideas provided by external sources (advisors, customers, training firms, } \\
\text { etc.) are considered useful instruments for my organization learning. }\end{array}$ \\
\hline & $\begin{array}{l}\text { Part of my organization culture is that employees can express their opinion and make } \\
\text { suggestion regarding the procedures and methods in place for carrying out tasks }\end{array}$ \\
\hline \multirow{4}{*}{$\begin{array}{l}\text { Knowledge transfer } \\
\text { and integration }\end{array}$} & Errors and failure are always discussed and analysed in my organization, on all levels \\
\hline & $\begin{array}{l}\text { Employees have the chance to talk among themselves about new ideas programs and } \\
\text { activities that might be of use to my organization. }\end{array}$ \\
\hline & In my organization, teamwork is not the usual way to work. (R) \\
\hline & $\begin{array}{l}\text { My organization has instruments (manual, databases, files, organizational routines, etc.) } \\
\text { that allow what has been learnt in the past situations to remain valid, although the } \\
\text { employees are no longer the same. }\end{array}$ \\
\hline
\end{tabular}

\subsection{Analysis}

We employed Smart Partial Least Square (Smart-PLS) version 2.0 to analyse the four sub-hypotheses. Based on Hair, Ringle, and Sarstedt (2011), analysis of the research model entails two stages of assessments. The first stage deals with the assessment of measurement model, which aims to assess the model's reliability and validity; whereas the second stage is the assessment of the structural model, which wishes at evaluating the significance of the proposed relationships and to estimate the amount of variance explained.

\section{Results}

\subsection{Sample Profile}

The respondents were requested to provide information about their age, years of working experience, gender, marital status, race, level of education, and income status. Out of 140 respondents, 85 respondents are male $(60.7 \%)$ and 55 respondents are female (39.3\%). In terms of marital, $54.3 \%$ are single while $45.7 \%$ are married. In term of race, majority of the respondents are Chinese (75.7\%), follow by Malay (12.1\%) and Indian (9.3\%). Other race consists of $2.9 \%$. In terms of age, $13.6 \%$ respondents fall into the age range of $18-25$ years old, $57.9 \%$ respondents in age range of 26-35 years old, $20.7 \%$ respondents in age range of 36-45 years old, $7.1 \%$ respondents in age range of 46-60 years old, and 7\% respondents in age range of above 60 years old. In terms of years of working experience, $44.3 \%$ respondents fall into the range of $0-5$ years, $27.1 \%$ in the range of $6-10$ years, $10.7 \%$ in the range of $11-15$ years, $12.1 \%$ in the range of $16-20$ years, $2.1 \%$ in the range of $21-25$ years, and 3.6\% in the range of 26-30 years. For the highest education qualification, $4.3 \%$ are holding certificate level, $6.4 \%$ are with Diploma, $76.4 \%$ are with Bachelor degree, $11.4 \%$ are with Masters and $1.4 \%$ is with $\mathrm{PhD}$. In terms of income, 2.9\% are below RM2000, 49.3\% fall between RM 2000 and RM 3999, 22.9\% are fall between RM 4000 to R.M 5999, 7.1\% are fall between RM 6000 to RM 6999, and 17.9\% are above RM 7000.

\subsection{Measurement Model Results}

Base on Table 2, all the items' loadings ranged from 0.560 to 0.892 , which fulfill the 0.50 minimum cut-off values (Hair et al., 2011). We also verify the convergent validity of the model using Average Variance Extracted (AVE), which is defined as the grand mean value of the square loadings of the indicators associated with the 
construct. The AVE of this study ranged from 0.524 to 0.760 and all exceeded the 0.50 threshold (Hair, Hult, Ringle, \& Sarstedt, 2013). Subsequently, the Composite reliability (CR) which ranged from 0.765 to 0.941 also exceeded the 0.70 ceiling value (Henseler, Ringle, \& Sinkovics, 2009). Our results grant evidence that the measurement model is reliable and has sufficient convergent validity.

Table 2. Items loadings, composite reliability, and the average variance extracted for the measurement model

\begin{tabular}{llllll}
\hline & Question Items & Loadings & AVE & Composite Reliability & R Square \\
\hline Creativity & RDC1 & 0.890 & 0.760 & 0.941 & 0.370 \\
& RDC2 & 0.892 & & & \\
& RDC3 & 0.858 & & & \\
& RDC4 & 0.834 & & & \\
Knowledge Transfer and Integration & RDC5 & 0.885 & & & \\
& TR1 & 0.696 & 0.524 & 0.765 \\
& TR2 & 0.831 & & & \\
Managerial Commitment & TR4 & 0.630 & & \\
Openness and Experimentation & MC1 & 0.819 & 0.571 & 0.800 \\
& MC4 & 0.627 & & & \\
& MC5 & 0.806 & & & \\
System Perspective & OE1 & 0.835 & 0.543 & 0.776 \\
& OE2 & 0.560 & & & \\
& OE4 & 0.785 & & & \\
& SP1 & 0.804 & 0.569 & 0.798 \\
& SP2 & 0.762 & & & \\
& SP3 & 0.693 & & & \\
\hline
\end{tabular}

The below table (Table 3) illustrates that the square root of AVE (diagonal values) is larger than correlations between constructs (off-diagonal values) which provide sufficient support for discriminate validity at construct level (Fornell \& Lacker, 1981).

Table 3. Discriminant validity of constructs

\begin{tabular}{|c|c|c|c|c|c|}
\hline & Creativity & $\begin{array}{ll}\text { Knowledge } & \\
\text { Transfer } \\
\text { Integration }\end{array}$ & $\begin{array}{l}\text { Managerial } \\
\text { Commitment }\end{array}$ & $\begin{array}{l}\text { Openness and } \\
\text { Experimentation }\end{array}$ & $\begin{array}{l}\text { System } \\
\text { Perspective }\end{array}$ \\
\hline Creativity & 0.872 & & & & \\
\hline $\begin{array}{l}\text { Knowledge Transfer } \\
\text { and Integration }\end{array}$ & 0.474 & 0.724 & & & \\
\hline $\begin{array}{l}\text { Managerial } \\
\text { Commitment }\end{array}$ & 0.4524 & 0.3624 & 0.756 & & \\
\hline $\begin{array}{l}\text { Openness } \\
\text { Experimentation }\end{array}$ & 0.4414 & 0.478 & 0.435 & 0.737 & \\
\hline System Perspective & 0.419 & 0.407 & 0.293 & 0.377 & 0.893 \\
\hline
\end{tabular}

Note: Diagonals (in bold) represent the squared roof of average variance extracted (AVE) while the others entries represent the correlations.

From Table 4, all items loaded highly on its respective construct and low on other construct which provide sufficient support for the convergent validity at item level as proposed by Chin (1998). 
Table 4. Loadings and cross loadings for the measurement model

\begin{tabular}{|c|c|c|c|c|c|}
\hline & Creativity & $\begin{array}{l}\text { Knowledge Transfer } \\
\text { and Integration }\end{array}$ & $\begin{array}{l}\text { Managerial } \\
\text { Commitment }\end{array}$ & $\begin{array}{ll}\text { Openness } & \text { and } \\
\text { Experimentation } & \end{array}$ & $\begin{array}{l}\text { System } \\
\text { Perspective }\end{array}$ \\
\hline $\mathrm{MC1}$ & 0.386 & 0.232 & 0.819 & 0.319 & 0.238 \\
\hline MC4 & 0.292 & 0.367 & 0.627 & 0.238 & 0.295 \\
\hline MC5 & 0.340 & 0.246 & 0.806 & 0.422 & 0.144 \\
\hline OE1 & 0.360 & 0.318 & 0.361 & 0.835 & 0.308 \\
\hline OE2 & 0.229 & 0.226 & 0.282 & 0.560 & 0.132 \\
\hline OE4 & 0.366 & 0.482 & 0.319 & 0.789 & 0.353 \\
\hline $\mathrm{RDC} 1$ & 0.890 & 0.429 & 0.465 & 0.366 & 0.402 \\
\hline RDC2 & 0.892 & 0.403 & 0.310 & 0.422 & 0.362 \\
\hline RDC3 & 0.858 & 0.328 & 0.363 & 0.324 & 0.383 \\
\hline RDC4 & 0.834 & 0.524 & 0.340 & 0.389 & 0.349 \\
\hline RDC5 & 0.885 & 0.368 & 0.480 & 0.419 & 0.333 \\
\hline SP1 & 0.371 & 0.287 & 0.234 & 0.148 & 0.804 \\
\hline SP2 & 0.270 & 0.381 & 0.163 & 0.284 & 0.762 \\
\hline SP3 & 0.294 & 0.267 & 0.260 & 0.461 & 0.693 \\
\hline TR1 & 0.266 & 0.696 & 0.391 & 0.312 & 0.274 \\
\hline TR2 & 0.430 & 0.837 & 0.151 & 0.422 & 0.345 \\
\hline TR4 & 0.302 & 0.630 & 0.320 & 0.285 & 0.254 \\
\hline
\end{tabular}

$\mathrm{MC}=$ managerial commitment; $\mathrm{OE}=$ Openness and experimentation; $\mathrm{RDC}=\mathrm{R} \& \mathrm{D}$ engineers' creativity; $\mathrm{SP}=$ System perspective; $\mathrm{TR}=$ Knowledge transfer and integration

\subsection{Structural Model Results}

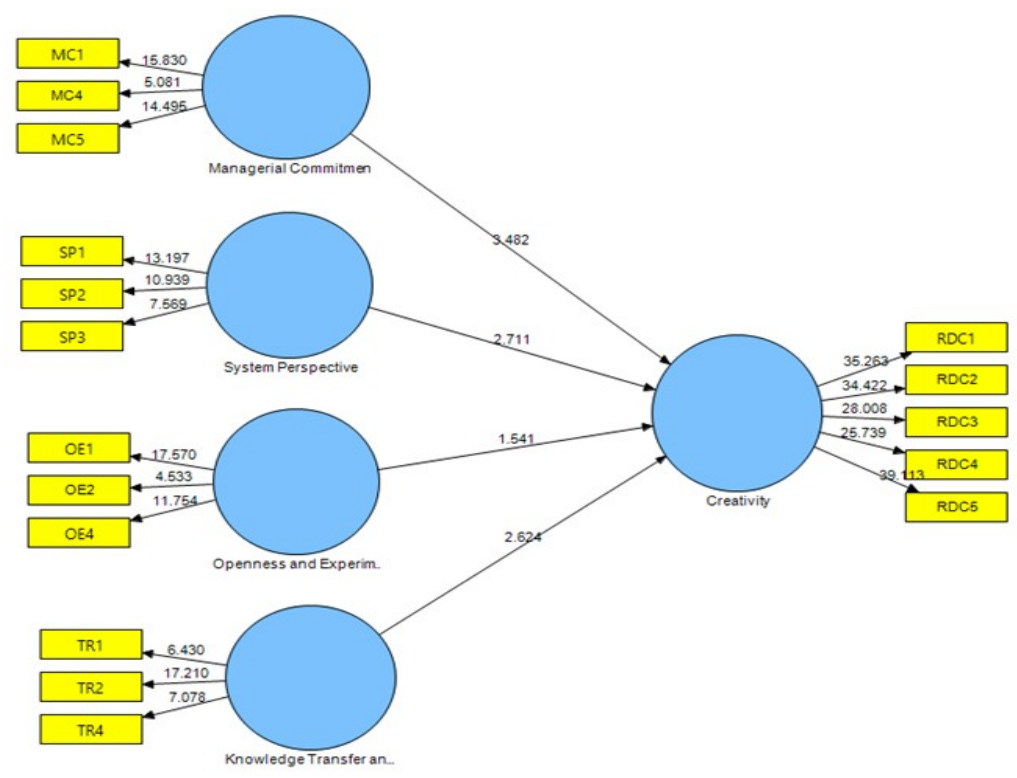

Figure 1. The structural model

The following step is to assess the structure model employing Bootstrapping procedure. Bootstrapping is a resampling technique that draw a large number of subsamples from the original data with replacement and estimates models for each subsample (Hair et al., 2013). Hair et al. (2013) mentioned that the number of bootstrap samples should be higher than the number of valid observations in the data. Although 5000 resample are recommended, but we decided to run the bootstrapping with 500 resample since the number of valid observations in this study is only 140. According to Chin (2010), the goodness of research model is established 
on the basis of the explained variance in endogenous construct $\left(\mathrm{R}^{2}\right)$ and the significance of all path coefficients $(\beta)$. The $\mathrm{R}^{2}$ refers to the amount of variance explained in the endogenous construct by its determinants in the research model. To achieve an acceptable level of explanatory power, the value of $\mathrm{R}^{2}$ shall be strong (Urbach \& Ahlemann, 2010). Based on Chin (1998), $\mathrm{R}^{2}$ values of 0.66, 0.33 and 0.19 are substantial, moderate and weak respectively. In this study, the $\mathrm{R}^{2}$ obtained is 0.370 , which reflects the model is moderate.

Hair et al. (2011) stated that critical t-values for one-tailed test are $1.65(\mathrm{p}<0.05)$, and $2.33(\mathrm{p}<0.01)$. Based on the results obtained in Table 5, three out of four dimensions were displaying significant relationship with R\&D engineers' creativity, namely managerial commitment $(\beta=0.245, \mathrm{p}<0.01)$, knowledge transfer and integration $(\beta=0.234, p<0.01)$, and system perspective $(\beta=0.196, p<0.01)$, while openness and experimental $(\beta=0.149$, $\mathrm{p}>0.05)$ show insignificant relationship.

Table 5. Summary of the structural model

\begin{tabular}{lllllll}
\hline Hypothesis & Path & $\begin{array}{l}\text { Beta } \\
\text { Value }\end{array}$ & $\begin{array}{l}\text { Standard } \\
\text { (STERR) }\end{array}$ & Error & t-value & Decision \\
\hline $\mathrm{H}_{1 \mathrm{a}}$ & $\begin{array}{l}\text { Knowledge Transfer and Integration }-> \\
\text { Creativity }\end{array}$ & 0.234 & 0.089 & 2.624 & Supported \\
$\mathrm{H}_{1 \mathrm{~b}}$ & $\begin{array}{l}\text { Managerial Commitment -> Creativity } \\
\text { Openness and Experimentation }->\end{array}$ & 0.245 & 0.070 & 3.482 & Supported \\
$\mathrm{H}_{1 \mathrm{c}}$ & $\begin{array}{l}\text { Creativity } \\
\mathrm{H}_{1 \mathrm{~d}}\end{array}$ & System Perspective -> Creativity & 0.196 & 0.096 & 1.541 & $\begin{array}{l}\text { Non } \\
\text { supported }\end{array}$ \\
\hline
\end{tabular}

**significant at $\mathrm{p}<0.01, *$ significant at $\mathrm{p}<0.05, \mathrm{~ns}=$ not supported, bootstrapping $(\mathrm{n}=500)$

\section{Discussion}

The ultimate goal of this research was to examine the level of R\&D engineers' creativity in Malaysia ODM industries. Specifically, the relationships between perceived managerial commitment, knowledge transfer and integration, openness and experimental, and system perspective was examined. The research found that only managerial commitment $(\mathrm{t}=3.482, \mathrm{p}<0.01)$, knowledge transfer and integration $(\mathrm{t}=2.624, \mathrm{p}<0.01)$, and system perspective $(t=2.711, p<0.01)$ had significant and positive relationship with $R \& D$ engineers' creativity, whereas openness and experimental $(\mathrm{t}=1.541, \mathrm{p}>0.05)$ had no significant relationship with R\&D engineers' creativity.

The result point toward that among the dimensions of organizational learning, managerial commitment has the highest influence on R\&D engineers' creativity. The R\&D engineers will be motivated when the management shows high commitment towards their new project. The R\&D engineer would perform better and more creative in contributing new ideas and solutions knowing that the management is standing behind him to ensure the project is successful. This result is contended with the finding from (Munns \& Bjeirmi, 1996) which implied that management commitment to continuously provide resources and administrative support is essential to increase employee's creativity level.

System perspective demonstrated the second higher influence on the R\&D engineers' creativity. The stronger system perspective would allow individual to mesh together better allowing a more effective information exchange and sharing. The R\&D engineers will be inspired to share new thoughts and be creativity in the work if the organization able to gather all its talents around as a single identity to innovate and improve the work together. This finding conjectures with Liao and Wu (2010) study that strong system perspective will increase the creativity level of its employees and then allow the organization to continually innovate the product.

Next, the knowledge transfer and integration has also demonstrated the significant relationship with R\&D engineers' creativity. This denotes that the integration and transfer of knowledge will lead to the creation of collective knowledge embedded in organizational memory which enable $R \& D$ engineer to retrieve for innovative solutions. The finding is in line with Cohen and Levinthal (1990) that the efficiency of knowledge transfer and integration rests on the individual knowledge absorptive capacity, which will in turn increase the individual creativity.

Although previous studies explicated that openness and experimentation positively contribute to creativity, however, openness and experimentation in this study was insignificant on R\&D engineers' creativity. One of the probable explanations is most of the R\&D engineers perceived that their organization didn't favor openness and also didn't accept all kinds of opinions and experimentation from them. Under this scenario, the R\&D engineers 
are not encourage to search for innovative procedure and method to solve current and future issues, therefore their creativity level will not be improved.

From the practical implication, the top management of the R\&D organization can refer the result of this study to improve the R\&D engineer creativity. The leadership of the ODM organization should put a model of organizational learning in place which would allow the propagation of internal learning within the company. Management should setup an avenue that enables employees to freely acquire and integrate different types of knowledge from internal (cross team and inter department) and external (supplier and competitor) members. Managers should also establish a platform to enable knowledge to be gathered, exchanged and combined from the source to an individual, team or even organization. Having a proper platform, the employees can use the knowledge in a wide array to create new solutions, improve efficiency and solve issues encountered. In this manner the R\&D engineers' creativity would be increased.

Although the findings of this study are able to present substantial answers to our research objectives, it needs to be carefully viewed with several limitations in this study. First and foremost, this study is limited to the ODM related sector companies located in Peninsular Malaysia. The findings may not be applicable to other regions. However in future, the research could be replicated with a larger sample to include other regions within the same industry, in order to improve the quality of the findings. Secondly, this study was limited to ODM industries which were specifically identified in the $10^{\text {th }}$ Malaysia Plan. However, other areas of interest can be considered in future research, such as the oil and gas industry and biotechnology industry. Besides, another growing sector service industry, such as telecommunication, healthcare and education also can be considered in future research.

\section{Conclusion}

The objective of this study was to examine the relationship between the perceived organizational learning and R\&D engineers' creativity within the context of the ODM companies in Malaysia. Form the findings, the proposed hypotheses were partly validated with three significant T-values. The significant relationships consist of managerial commitment, system perspective and knowledge transfer and integration which are perceived to be directly contributed to R\&D engineers' creativity. In sum, all the three dimensions of organizational learning are viewed imperative to increase the R\&D engineers' creativity level. On the other hand, the openness and experimentation is not significantly influences the R\&D engineers' creativity partly may due to the culture of the organizations surveyed are not favor openness. This factor may be able to further validated through the interview with the participated companies in this study in the near future.

\section{Acknowledgments}

The author would like to extend her gratitude to the Universiti Sains Malaysia for providing the grant (304/PPAMC/6313051) to fund this research.

\section{References}

Agency for Science, Technology and Research Singapore. (2012). National Survey of Research and Development in Singapore 2012. Singapore: Agency for Science, Technology and Research Singapore.

Akgun, A. E., Byrne, J. C., Lynn, G. S., \& Keskin, H. (2007). Organizational unlearning as changes in beliefs and routines in organizations. Journal of Organizational Change Management, 20(6), 794-812. http://dx.doi. org/10.1108/09534810710831028

Alegre, J., \& Chiva, R. (2008). Assessing the impact of organizational learning capability on product innovation performance: An empirical test. Technovation, 28(1), 315-326. http://dx.doi.org/10.1016/j.technovation. 2007.09.003

Amabile, T. M., Schatzel, E. A., Moneta, G. B., \& Kramer, S. J. (2004). Leader behaviors and the work environment for creativity: Perceived leader support. The Leadership Quarterly, 15(1), 5-32. http://dx.doi. org/10.1016/j.leaqua.2003.12.003

Asmawi, A., \& Mohan, A. (2010). Understanding patterns of organizational culture: A study in Malaysian R\&D institutions. Paper presented at Management of Innovation and Technology (ICMIT), 2010 IEEE International Conference (pp. 324-329). Singapore. http://dx.doi.org/10.1109/ICMIT.2010.5492710

Batey, M., \& Furnham, A. (2006). Creativity, intelligence, and personality: A critical review of the scattered literature. Genetic, Social, and General Psychology Monographs, 132(4), 355-429. http://dx.doi.org/10. 3200/MONO.132.4.355-430

Berg, H., Taatila, V., \& Volkmann, C. (2012). Fostering creativity - A holistic framework for teaching creativity. Development and Learning in Organizations, 26(6), 5-8. http://dx.doi.org/10.1108/14777281211272242

Camison, C., \& Fores, B. (2010). Knowledge absorptive capacity: New insights for its conceptualization and 
measurement. Journal of Business Research, 63(7), 707-715. http://dx.doi.org/10.1016/j.jbusres.2009. 04.022

Chang, J. C., Yeh, Y. M., Chen, S. C., \& Hsiao, H. C. (2011). Taiwanese technical education teacher's profes-sional development: An examination of some critical factors. Teaching and teacher education, 27(1), 161-173. http://dx.doi.org/10.1016/j.tate.2010.07.013

Chen, J. C., Silverthorne, C., \& Hung, J. Y. (2006). Organization communication, job stress, organizational commitment, and job performance of accounting professionals in Taiwan and America. Leadership \& Organization Development Journal, 27(4), 242-249. http://dx.doi.org/10.1108/01437730610666000

Chen, W. L., Sandhu, M. S., \& Jain, K. K. (2009). Knowledge sharing in an American multinational company based in Malaysia. Journal of Workplace Learning, 21(2), 125-142. http://dx.doi.org/10.1108/13665620910 934825

Chin, W. W. (1998). The Partial Least Squares Approach to Structural Equation Modeling. In G. A. Marcoulides (Ed.), Modern Methods for Business Research (pp. 295-336). Mahwah, NJ: Lawrence Erlbaum Associates, Publisher.

Chin, W. W. (2010). How to write up and report PLS analyses. In V. Esposito et al. (Eds.), Handbook of Partial Least Squares (pp. 655-688). New York: Springer-Verlag.

Chiva, R., Alegre, J., \& Lapiedra, R. (2007). Measuring organisational learning capability among the workforce. International Journal of Manpower, 28(3/4), 224-242. http://dx.doi.org/10.1108/01437720710755227

Cohen, W. M., \& Levinthal, D. A. (1990). Absorptive capacity: A new perspective on learning and innovation. Administrative Science Quarterly, 35(1), 128-152. http://dx.doi.org/10.2307/2393553

Cornell University, INSEAD, \& WIPO (2014). The Global Innovation Index 2014: The Human Factor In innovation. Fontainebleau, Ithaca, and Geneva.

Daft, R. L., \& Weick, K. E. (1984). Toward a model of organizations as interpretation systems. Academy of Management Review, 9(2), 284-295.

Darroch, J., \& McNaughton, R. (2002). Examining the link between knowledge management practices and types of innovation. Journal of intellectual capital, 3(3), 210-222. http://dx.doi.org/10.1108/14691930210435570

De Geus, A. P. (1988). Planning as learning, Harvard Business Review, 66(2), 70-74.

Donnelly, B. (1994). Creativity at the workplace. The Journal of Technology Studies, 20(2), 4-8.

Economic Planning Unit. (2010). Tenth Malaysia Plan 2011-2015. Putra Jaya, Malaysia: Prime Minister Department.

Egan, T. M., Yang, B., \& Bartlett, K. R. (2004). The effects of organizational learning culture and job satisfaction on motivation to transfer learning and turnover intention. Human resource development quarterly, 15(3), 279-301. http://dx.doi.org/10.1002/hrdq.1104

Escriba-Esteve, A., \& Montoro-Sanchez, A. (2012). Guest editorial: Creativity and innovation in the firm: Managerial antecedents and effects on employees. International Journal of Manpower, 33(4), 344-348. http://dx.doi.org/10.1108/01437721211243796

Federation of Malaysia Manufacturer. (2013). Federation of Malaysia Manufacturer Directory (44th ed.). Kuala Lumpur: Federation of Malaysia Manufacturer.

Fornell, C., \& Larcker, D. F. (1981). Evaluating structural equation models with unobservable variables and measurement error. Journal of Marketing Research, 18(1), 39-50. http://dx.doi.org/10.2307/3151312

García-Morales, V. J., Lloréns-Montes, F. J., \& Verdú-Jover, A. V. (2007). Influence of personal mastery on organizational performance through organizational learning and innovation in large firms and SMEs. Technovation, 27(9), 547-568. http://dx.doi.org/10.1016/j.technovation.2007.02.013

Hair J. F., Hult, G. T. M., Ringle, C., \& Sarstedt, M. (2013). A Primer on Partial Least Squares Structural Equation Modeling (PLS-SEM). SAGE Publications, Incorporated.

Hair, J. F., Ringle, C. M., \& Sarstedt, M. (2011). PLS-SEM: Indeed a Silver Bullet. Journal of Marketing Theory and Practice, 19(2), 139-151. http://dx.doi.org/10.2753/MTP1069-6679190202

Henseler, J., Ringle, C. M., \& Sinkovics, R. R. (2009). The use of partial least squares path modeling in international marketing (Vol. 20). Emerald Group Publishing Limited.

Houghton, J. D., \& DiLiello, T. C. (2010). Leadership development: The key to unlocking individual creativity in organizations. Leadership \& Organization Development Journal, 31(3), 230-245. http://dx.doi.org/10. $1108 / 01437731011039343$

Hwang, J., \& Kandampully, J. (2012). The role of emotional aspects in younger consumer-brand relationships. 
The Journal of Product and Brand Management, 21(2), 98-108. http://dx.doi.org/10.1108/1061042121 1215517

Jamal, M. (2011). Job stress, job performance and organizational commitment in a multinational company: An empirical study in two countries. International Journal of Business and Social Science, 2(20), 20-29.

Jerez-Gomez, P., Céspedes-Lorente, J., \& Valle-Cabrera, L. (2005). Organizational learning and compensation strategies: Evidence from the Spanish chemical industry. Human Resource Management, 44(3), 279-299. http://dx.doi.org/10.1002/hrm.20071

Liao, S. H., \& Wu, C. C. (2010). System perspective of knowledge management, organizational learning, and organizational innovation. Expert Systems with Applications, 37(2), 1096-1103. http://dx.doi.org/10.1016/j. eswa.2009.06.109

Lin, H. F. (2008). Empirically testing innovation characteristics and organizational learning capabilities in e-business implementation success. Internet Research, 18(1), 60-78. http://dx.doi.org/10.1108/1066224 0810849595

Munns, A., \& Bjeirmi, B. F. (1996). The role of project management in achieving project success. International Journal of Project Management, 14(2), 81-87. http://dx.doi.org/10.1016/0263-7863(95)00057-7

Nettle, D. (2002). Strong Imagination: Madness, Creativity, and Human Nature. Oxford, UK: Oxford University Press.

Nonaka, I., \& Peltokorpi, V. (2006). Objectivity and subjectivity in knowledge management: A review of 20 top articles. Knowledge and Process Management, 13(2), 73-82. http://dx.doi.org/10.1002/kpm.251

Performance Management and Delivery Unit (PEMANDU). (2012a). Economic Transformational Programme Annual Report 2012. Putra Jaya, Malaysia: Prime Minister Department.

Performance Management and Delivery Unit (PEMANDU). (2012b). Economic Transformational Programme: A Road Map for Malaysia. Putra Jaya, Malaysia: Prime Minister Department.

Performance Management and Delivery Unit. (2011). Economic Transformation Programme Annual Report 2011. Putra Jaya, Malaysia: Prime Minister Department.

Rhodes, J., Lok, P., Hung, R. Y. Y., \& Fang, S. C. (2008). An integrative model of organizational learning and social capital on effective knowledge transfer and perceived organizational performance. Journal of Workplace Learning, 20(4), 245-258. http://dx.doi.org/10.1108/13665620810871105

Senge, P. M., Kleiner, A., Roberts, C., Ross, R., Roth, G., \& Smith, B. (1999). The Dance of Change: The Challenges to Sustaining Momentum in a Learning Organization. New York: Random House LLC.

Shalley, C. E., \& Gilson, L. L. (2004). What leaders need to know: A review of social and contextual factors that can foster or hinder creativity? The Leadership Quarterly, 15(1), 33-53. http://dx.doi.org/10.1016/j.leaqua. 2003.12.004

Sinkula, J. M. (1994). Market information processing and organizational learning. Journal of Marketing, 58(1), 35-45. http://dx.doi.org/10.2307/1252249

Small, A., \& Irvine, P. (2006). Towards a framework for organizational learning. The Learning Organization, 13(3), 276-299. http://dx.doi.org/10.1108/09696470610661126

Urbach, N., \& Ahlemann, F. (2010). Structural equation modeling in information systems research using partial least squares. Journal of Information Technology Theory and Application, 11(2), 5-40.

Ussahawanitchakit, P. (2008). Building job satisfaction of certified public accountants (CPAs) in Thailand: Effects of role stress through role conflict, role ambiguity, and role overload. Journal of Academy of business and economics, 8(2), 12-22.

Voltmer, E., Rosta, J., Siegrist, J., \& Aasland, O. G. (2012). Job stress and job satisfaction of physicians in private practice: Comparison of German and Norwegian physicians. International Archives of Occupational and Environmental Health, 85(7), 819-828. http://dx.doi.org/10.1007/s00420-011-0725-5

\section{Copyrights}

Copyright for this article is retained by the author(s), with first publication rights granted to the journal.

This is an open-access article distributed under the terms and conditions of the Creative Commons Attribution license (http://creativecommons.org/licenses/by/3.0/). 